\title{
Control of Hard to Manage Weeds along Highway Rights-of-Way 1
}

\author{
Jason Ferrell and Ken Langeland ${ }^{2}$
}

Table 1. Control of upland invasive weeds

\begin{tabular}{|c|c|c|}
\hline Herbicide & Rate & Comments \\
\hline \multicolumn{3}{|c|}{ Cogongrass } \\
\hline $\begin{array}{l}\text { Glyphosate } \\
\text { (Roundup Pro, etc) }\end{array}$ & $\begin{array}{l}4 \text { to } 8 \mathrm{pt} / \mathrm{A} \\
\text { or } \\
3 \text { to } 5 \% \text { solution }\end{array}$ & $\begin{array}{l}\text { Cogongrass is most sensitive to glyphosate when applied } \\
\text { in the fall. Spring applications are less effective. Mowing } \\
\text { existing vegetation and treating the regrowth approximately } \\
2 \text { weeks later is often best. } \\
\text { Multiple applications are often required before complete } \\
\text { control is achieved. }\end{array}$ \\
\hline $\begin{array}{l}\text { Arsenal or Arsenal } \\
\text { Powerline* } \\
\text { BASF Corp }\end{array}$ & $\begin{array}{l}64 \mathrm{fl} \mathrm{oz/A} \text { or } \\
1 \% \text { solution }\end{array}$ & $\begin{array}{l}\text { Cogongrass is most sensitive to when applied in the fall. } \\
\text { Spring applications are less effective. Mowing existing } \\
\text { vegetation and treating the regrowth approximately } 2 \\
\text { weeks later is often best. } \\
\text { Arsenal is more effective on cogongrass than glyphosate, } \\
\text { but expect total vegetation control and bare ground for } 2 \text { to } \\
4 \text { months after application. DO NOT apply Arsenal over the } \\
\text { root zone of desirable hardwood trees. Multiple } \\
\text { applications are often required before complete control is } \\
\text { achieved. }\end{array}$ \\
\hline
\end{tabular}

1. This document is SS AGR 275, one of a series of the Agronomy Department, Florida Cooperative Extension Service, Institute of Food and Agricultural Sciences, University of Florida. Original publication date September 2007. Visit the EDIS Web Site at http://edis.ifas.ufl.edu.

2. Jason Ferrell, assistant professor, Agronomy Department; Ken Langeland, professor, Agronomy Department, Florida Cooperative Extension Service, Institute of Food and Agricultural Sciences, University of Florida, Gainesville, FL 32611.

The use of trade names in this publication is solely for the purpose of providing specific information. UF/IFAS does not guarantee or warranty the products named, and references to them in this publication does not signify our approval to the exclusion of other products of suitable composition. All chemicals should be used in accordance with directions on the manufacturer's label.

The Institute of Food and Agricultural Sciences (IFAS) is an Equal Opportunity Institution authorized to provide research, educational information and other services only to individuals and institutions that function with non-discrimination with respect to race, creed, color, religion, age, disability, sex, sexual orientation, marital status, national origin, political opinions or affiliations. U.S. Department of Agriculture, Cooperative Extension Service, University of Florida, IFAS, Florida A. \& M. University Cooperative Extension Program, and Boards of County Commissioners Cooperating. Larry Arrington, Dean 
Table 1. Control of upland invasive weeds

\begin{tabular}{|c|c|c|}
\hline Herbicide & Rate & Comments \\
\hline \multicolumn{3}{|c|}{ Tropical Soda Apple } \\
\hline Garlon 4 Ultra & $\begin{array}{l}1 \mathrm{qt} / \mathrm{A} \\
\text { or } \\
0.5 \% \text { solution for spot application }\end{array}$ & $\begin{array}{l}\text { A broadcast application of Garlon } 4 \text { is effective on TSA if } \\
\text { applied near blooming or after regrowth from mowing. } \\
\text { Applications made in late summer months or while fruiting } \\
\text { are less effective. Garlon } 4 \text { has no soil residual activity and } \\
\text { recolonization from seed is likely to occur after application. } \\
\text { If spot-spraying, it is important to achieve full coverage. } \\
\text { The Organo-auxin rule must be obeyed when using } \\
\text { this herbicide. }\end{array}$ \\
\hline Milestone VM & $\begin{array}{l}5 \text { to } 7 \mathrm{fl} . \mathrm{oz} / \mathrm{A} \\
\text { or } \\
0.1 \% \text { solution for spot application }\end{array}$ & $\begin{array}{l}\text { A broadcast application of Milestone VM is effective on } \\
\text { TSA at any growth stage or time of year. Mowing is not } \\
\text { necessary to improve control. Milestone VM has significant } \\
\text { soil residual activity and control of seedlings is likely to } \\
\text { occur for over } 6 \text { months after application. } \\
\text { If spot-spraying, it is important to achieve full coverage. } \\
\text { The Organo-auxin rule must be obeyed when using } \\
\text { this herbicide. }\end{array}$ \\
\hline \multicolumn{3}{|c|}{ Brazilian Pepper or Chinese Tallow } \\
\hline Garlon 4 & $10 \%-25 \%$ diluted in oil & $\begin{array}{l}\text { Basal bark or cut-stump application, rate will depend on } \\
\text { applicator technique and site conditions, e.g. soil water } \\
\text { content. }\end{array}$ \\
\hline $\begin{array}{l}\text { Pathfinder II or } \\
\text { Remedy RTU } \\
\end{array}$ & Undiluted & Basal bark application \\
\hline Garlon 3A & $50-100 \%$ & $\begin{array}{l}\text { Cut stump application. Apply herbicide immediately after } \\
\text { felling. }\end{array}$ \\
\hline Garlon 3A & $0.50-1.5 \%$ & Brazilian pepper only. Foliar application. Use sufficient \\
\hline Escort XP & 1-2 oz/acre & volume to ensure thorough coverage. \\
\hline \multicolumn{3}{|r|}{ Kudzu } \\
\hline Escort XP* & $3-4 \mathrm{oz} / \mathrm{A}$ & $\begin{array}{l}\text { Apply Escort XP when kudzu is actively growing for } \\
\text { optimum control. Several hardwood species are sensitive } \\
\text { to Escort XP at these rates. Escort XP should not be used } \\
\text { for kudzu control if desirable hardwoods are present. }\end{array}$ \\
\hline Transline* $\dagger$ & 5 to $21 \mathrm{fl} \mathrm{oz/A}$ & $\begin{array}{l}\text { Transline should be applied from late summer through fall } \\
\text { for optimum control. For small populations that are not well } \\
\text { established, lower application rates are acceptable. For } \\
\text { larger, more mature stands, the maximum application rate } \\
\text { should be used. Transline is safer on hardwood species } \\
\text { than Escort XP. } \\
\text { Transline is only labeled for use in select counties in North } \\
\text { Florida. See product label for specifics. } \\
\text { The Organo-auxin rule must be obeyed when using } \\
\text { this herbicide. }\end{array}$ \\
\hline
\end{tabular}


Table 1. Control of upland invasive weeds

\begin{tabular}{|l|l|l|}
\hline Herbicide & Rate & Comments \\
\hline $\begin{array}{l}\text { Glyphosate } \\
\text { (Roundup Pro, etc) }\end{array}$ & $1-2 \%$ solution & $\begin{array}{l}\text { Air Potato } \\
\text { such as August-October. Early-season applications may } \\
\text { require repeat treatments, and applications made after } \\
\text { plants begin yellowing result in limited control. Desirable } \\
\text { vegetation under air potato may not be damaged when } \\
\text { lower rates of glyphosate are used. Removal of bulbils from } \\
\text { the ground will aid long term control. }\end{array}$ \\
\hline Escort XP* & $\begin{array}{l}1-2 \mathrm{oz} / \mathrm{A} \\
\text { or } 2 \mathrm{oz} / 100 \text { gallon }\end{array}$ & $\begin{array}{l}\text { Apply Escort XP or glyphosate to all live fronds for best } \\
\text { results. Treatment of Lygodium often results in non-target } \\
\text { damage due to the climbing nature of these species. In } \\
\text { long-established stands of Lygodium, re-treatment will be } \\
\text { required in < 6 months due to re-sprouts and new fern } \\
\text { growth from spores. If not included in the product, an } \\
\text { appropriate NIS surfactant at 0.5\% v/v should be added to } \\
\text { the herbicide solution. For fronds growing high in trees, cut } \\
\text { at waist level and treat remaining rooted fronds. }\end{array}$ \\
\hline $\begin{array}{l}\text { Glyphosate (Rodeo, } \\
\text { Roundup Pro, etc) }\end{array}$ & $\begin{array}{l}7.5 \text { pints/A } \\
\text { or } \\
2 \% \text { solution }\end{array}$ &
\end{tabular}

${ }^{*}$ denotes products not currently found on the DOT bid list.

$\dagger$ Transline is only labeled for use in specific counties in Florida.

Table 1. Control of upland invasive weeds

\begin{tabular}{|l|l|l|}
\hline Herbicide & Rate & Comments \\
\hline
\end{tabular}


Table 2. Aquatic Vegetation Control

\begin{tabular}{|c|c|c|}
\hline Herbicide & Rate & Comments \\
\hline \multicolumn{3}{|c|}{ Cattail } \\
\hline $\begin{array}{l}\text { Habitat } \\
\text { BASF Corp }\end{array}$ & $\begin{array}{l}32 \mathrm{fl} \mathrm{oz/A} \\
\text { Surfactant required: } \\
0.5 \% \mathrm{v} / \mathrm{v} \text { NIS or } 1 \% \mathrm{v} / \mathrm{v} \text { MSO }\end{array}$ & $\begin{array}{l}\text { Apply to actively growing cattails in the spring, summer, or } \\
\text { fall . DO NOT apply in the root zones of desirable } \\
\text { hardwood vegetation. Do not apply to irrigation water } \\
\text { The addition of an approved aquatic surfactant is required. }\end{array}$ \\
\hline $\begin{array}{l}\text { Clearcast } \\
\text { BASF Corp }\end{array}$ & $\begin{array}{l}64 \mathrm{fl} \mathrm{oz} / \mathrm{A} \\
\text { Surfactant required: } \\
0.5 \% \mathrm{v} / \mathrm{v} \mathrm{NIS} \text { or } 1 \% \mathrm{v} / \mathrm{v} \mathrm{MSO}\end{array}$ & $\begin{array}{l}\text { Apply to actively growing cattails in the spring, summer, or } \\
\text { fall . Can be used in the root zones of desirable hardwood } \\
\text { vegetation. Refer to current label for irrigation and watering } \\
\text { restrictions. } \\
\text { The addition of an approved aquatic surfactant is required. }\end{array}$ \\
\hline $\begin{array}{l}\text { Glyphosate (Rodeo, } \\
\text { Accord Concentrate, } \\
\text { etc.) }\end{array}$ & $7.5 \mathrm{pt} / \mathrm{A}$ or $0.75-1.5 \%$ solution & $\begin{array}{l}\text { Fall applications are most effective. } \\
\text { The addition of an approved aquatic surfactant is required. }\end{array}$ \\
\hline \multicolumn{3}{|c|}{ Alligator weed } \\
\hline $\begin{array}{l}\text { Habitat* } \\
\text { BASF Corp }\end{array}$ & $\begin{array}{l}32 \mathrm{fl} \mathrm{oz/A} \\
\text { Surfactant required: } \\
0.5 \% \mathrm{v} / \mathrm{v} \text { NIS or } 1 \% \mathrm{v} / \mathrm{v} \text { MSO }\end{array}$ & $\begin{array}{l}\text { Apply to actively growing alligator weed in the spring, } \\
\text { summer, or fall. DO NOT apply in the root zones of } \\
\text { desirable hardwood vegetation. Do not apply to irrigation } \\
\text { water }\end{array}$ \\
\hline $\begin{array}{l}\text { Clearcast* }^{*} \\
\text { BASF Corp }\end{array}$ & $\begin{array}{l}64 \mathrm{fl} \mathrm{oz/A} \\
\text { Surfactant required: } \\
0.5 \% \mathrm{v} / \mathrm{v} \text { NIS or } 1 \% \mathrm{v} / \mathrm{v} \mathrm{MSO}\end{array}$ & $\begin{array}{l}\text { Apply to actively growing alligator weed in the spring. For } \\
\text { summer and fall applications, add glyphosate } 32 \mathrm{fl} \mathrm{oz/A} \text {. } \\
\text { Can be used in the root zones of desirable hardwood } \\
\text { vegetation. Refer to current specimen label for irrigation } \\
\text { and watering restrictions. }\end{array}$ \\
\hline $\begin{array}{l}\text { Glyphosate (Rodeo, } \\
\text { etc) }\end{array}$ & $0.75-1.5 \%$ solution & $\begin{array}{l}\text { Repeat applications will be necessary. Addition of } \\
\text { approved surfactant is necessary. }\end{array}$ \\
\hline Renovate & $3-8 \mathrm{qt} /$ acre or $.75-1.0 \%$ solution & $\begin{array}{l}\text { Repeat treatments will be necessary, especially to floating } \\
\text { mats. Additional surfactant may improve performance. }\end{array}$ \\
\hline \multicolumn{3}{|c|}{ Water Hyacinth } \\
\hline 2,4-D amine* & $\begin{array}{l}2-4 \text { qt per acre or } 0.5-1.0 \% \\
\text { solution }\end{array}$ & $\begin{array}{l}\text { Refer to specific product label to ensure that the } 2,4-D \\
\text { brand used is labeled for aquatic weed control. Refer to } \\
\text { label for water use restrictions. }\end{array}$ \\
\hline Reward & $0.5-2.0 \mathrm{gal} / \mathrm{acre}$ or $0.5 \%$ solution & $\begin{array}{l}\text { Addition of an approved surfactant is essential. Refer to } \\
\text { label for water use restrictions. }\end{array}$ \\
\hline $\begin{array}{l}\text { Glyphosate (Rodeo, } \\
\text { etc) }\end{array}$ & $\begin{array}{l}5-6 \text { pints per acre or } 0.75-1.0 \% \\
\text { solution }\end{array}$ & $\begin{array}{l}\text { Addition of an approved surfactant is essential. Refer to } \\
\text { label for water use restrictions. Visual symptom are not } \\
\text { observed until over three weeks after application. }\end{array}$ \\
\hline \multicolumn{3}{|c|}{ Water Lettuce } \\
\hline Reward & $\begin{array}{l}0.5-1.0 \mathrm{gal} / \mathrm{acre} \text { or } 0.5 \text { to } 1.0 \% \\
\text { solution }\end{array}$ & Addition of an approved surfactant is essential. \\
\hline Stingray & 3.4-13.5 oz/acre & Addition of an approved surfactant is necessary. \\
\hline \multicolumn{3}{|c|}{ Torpedograss } \\
\hline $\begin{array}{l}\text { Glyphosate (Rodeo, } \\
\text { etc.) }\end{array}$ & $2-3 \%$ solution & \multirow{2}{*}{$\begin{array}{l}\text { Torpedograss control will be improved when maximum leaf } \\
\text { surface is exposed above the water line. Regardless of } \\
\text { herbicide or application rate, multiple applications will be } \\
\text { required for complete control. } \\
\text { The addition of an approved aquatic surfactant is required. }\end{array}$} \\
\hline Habitat & $1 \%$ solution & \\
\hline
\end{tabular}

* denotes products not currently found on the DOT bid list.

$\dagger$ Transline is only labeled for use in specific counties in Florida. 